\title{
Urban ecosystem services in strategic planning in Swedish municipalities
}

\author{
Åsa Ode Sang ${ }^{1}$ (D) . Frederik Aagaard Hagemann ${ }^{1} \cdot$ Nils Ekelund $^{2} \cdot$ Jessica Svännel $^{1}$
}

Accepted: 14 February 2021 / Published online: 7 April 2021

(C) The Author(s) 2021

\begin{abstract}
Research to date on urban ecosystem services has mainly been conducted in large cities, particularly in China, the USA and some European countries. This study examined the provision of urban ecosystem services in a Swedish municipality context, based on interviews with municipal stakeholders in strategic management and planning from six municipalities and a review of existing publications readily available to practitioners. The analysis focused on (1) the ecosystem services explicitly covered, (2) whether multifunctionality was covered and specific synergies and trade-offs identified and, (3) the spatial scale and context used for ecosystem services (valuation/mapping, planning, design or maintenance) in practical application. The results showed that regulatory services are very much the focus in municipal operations as well as in publications available to practitioners. This is reflected in the implementation of the concept through problem solving often related to regulatory services, using multifunctionality and win-win situations in ecosystem service supply. These findings contribute to the growing body of work exploring how the concept of ecosystem services is adapted and utilised in practice.
\end{abstract}

Keywords Urban ecosystem service $\cdot$ Practical implementation $\cdot$ Strategic planning and management $\cdot$ Municipality

\section{Introduction}

Urbanisation is increasing rapidly worldwide, putting pressure on the resources available to provide liveable cities (Kotzeva and Brandmüller 2016). Urban ecosystem services can make a visible and measurable contribution to human well-being, providing a valuable approach for safeguarding viable and healthy cities for the future. Thus urban ecosystem services have been the subject of much research, although heavily dominated by studies carried out in large cities in China, the USA and some

Åsa Ode Sang

asa.sang@slu.se

Frederik Aagaard Hagemann

Frederik.aagaard.hagemann@slu.se

Nils Ekelund

nils.ekelund@mau.se

Jessica Svännel

Jessica.svannel@slu.se

1 Department of Landscape Architecture, Planning and Management, Swedish University of Agricultural Sciences, Alnarp, Sweden

2 Department Natural Sciences, Mathematics, Society, Malmö University, Malmö, Sweden particular European countries (Haase et al. 2014; Hansen et al. 2015; Luederitz et al. 2015). It has also been demonstrated that most of the focus in research has so far been on single ecosystem services with limited exploration of co-benefits and synergies between services (Haase et al. 2014; Keeler et al. 2019). The focus of the studies are dominated by regulating services, closely followed by provisioning services with cultural and supporting services only considered half as frequently (Luederitz et al. 2015). The benefit of the ecosystem services concept in an urban context is its ability to promote multifunctional green space planning (e.g. Hansen and Pauleit 2014; Wang and Banzhaf, 2018). A recent review of ecosystem services in relation to multifunctional urban green spaces found that only $25 \%$ of the 94 papers reviewed covered all four groups of ecosystem services (Charoenkit and Piyathamrongchai 2019). It further showed, similar to the Luederitz et al. 2015 review, that regulatory services were included in $90 \%$ of studies. However, in relation to multifunctionality, cultural ecosystem services were included in $70 \%$ of the studies, supporting services in $52 \%$ of the studies and provisioning in $43 \%$ of the studies, with regulating and cultural services the most frequently combined (Charoenkit and Piyathamrongchai 2019). In contrast, when looking at multifunctional landscapes in a non-urban focus, supporting services dominated in $79 \%$ of the papers, followed by regulating (69\%), provisioning (43\%) and cultural ecosystem 
services (37\%) (Hölting et al. 2019). Multifunctional green structure/green space is a useful concept for exploring tradeoffs and synergies within spatial planning, emphasising the multiple functions of the urban ecosystem and fitting well within the research discourse on ecosystem services (de Groot et al. 2010; Hansen and Pauleit, 2014). The research review by Lee and Lautenbach (2016) identified synergestic relationships mainly between regulating and cultural ecosystem services, while there were trade-offs between provisioning and regulating ecosystem services. However, there is a knowledge gap with regard to the specific synergies and trade-offs of ecosystem services occuring wihtin spatial planning (Sussams et al. 2015).

There have been several studies carried out globally exploring the applicability of the concept of ecosystem services within green structure planning practice, showing the concept as being positively received by the practice as a way of integrating multiple values of nature into planning (see for instance Andersson-Sköld et al. 2018a; Beery et al. 2016; Hansen et al. 2015; Jaligot and Chenal 2019; La Rosa, 2019; Mascarenhas et al. 2015; Rall et al. 2015; Schubert et al. 2018; Woodruff and BenDor 2016). However, several of the studies stress that the use of the concept is often more conceptual rather than as a strategic tool (e.g. Beery et al. 2016; La Rosa 2019; Schubert et al. 2018). This is despite the oftenexpressed potential of the concept in research, to aid in the understanding of specific trade-offs relating to changes in land use, changes in management objectives, technical vs. naturebased solutions, use of natural resources and management of conflict species (Haase et al. 2014; Turkelboom et al. 2018).

Findings show that the integration of the concept into planning is promoted through high-level policies, with variations between countries in terms of the inclusion of ecosystem services (Hansen et al. 2015). Sweden is recognised as a country that entered the ecosystem service discourse in an early stage, which is also reflected on a policy level. Under a Swedish parliament decree, the value of ecosystem services has had to be made generally well known and integrated into key decision making from 2018 onwards (e.g. SEPA 2012). To this end, the Swedish Environmental Protection Agency (SEPA) introduced a communication strategy that is reported to have been successful, with increased awareness and understanding of the value of ecosystem services across different sectors (e.g. Boverket 2017; SEPA 2018). The next target is for 2025, by which time the majority of Swedish municipalities must have integrated ecosystem services into the planning, building and governance of the urban built environment. Hence, Sweden is a country in which it is expected that the concept of urban ecosystem services will be implemented in various parts of the strategic planning and management of green structure. Studies in Sweden have shown the concept of ecosystem services as having a wide acceptance into practice, with the concept being recognised as a useful tool for strategic planning and management of urban green structure by the practice (Andersson-Sköld et al. 2018a; Beery et al. 2016; Schubert et al. 2018). However, these studies also identified a need for support, clear guidance and consistent definitions in order to support further implementation of the concept in Swedish municipalities (Beery et al. 2016; Schubert et al. 2018).

In the present study, we used the Swedish municipality context to explore how practice is matched and reflected by the available guidance published and the current research within the field. This was conducted through interviews with practitioners, combined with a review of practice guidelines where we addressed the following research questions: 1) what ecosystem services are the main focus; 2) how are multifunctionality, synergies and trade-offs between ecosystem services understood; and 3) what are the spatial scales on which solutions for ecosystem service benefits are implemented.

\section{Method}

This study uses a triangulation mixed method approach were semi-structured interviews are complemented with a review of guidelines for municipal planning in order to address the research questions. The interviews capture the experiences and views of the practitioners on the status of ecosystem service implementation. The main source for planners and managers to gain information on current research, translated into a Swedish context, consists of the guidelines in Swedish. Hence, the review of the guidelines will provide information in Swedish on what research is made more widely available for the practice. Results from both methods are summarised in tables and graphs, with the results from both methods brought together in the discussion. A combination of the review of the guidelines and the qualitative accounts from key stakeholders will provide an overview of key ecosystem services prioritised in Swedish municipal practice, further nuanced by an account of multifunctionality, trade-offs and scales of implementation for these services.

\section{Typology for ecosystem services}

As part of the work to apply the concept within Swedish spatial planning, the Swedish National Board of Housing, Building and Planning (Boverket) has developed its own typology for urban ecosystem services (Boverket 2019b). The typology developed by Boverket, which identifies 22 services, is based on the experiences from the $\mathrm{C} / \mathrm{O}$ City (Keane et al. 2014) project.C/O City was a national transdisciplinary project involving various stakeholders in urban planning, such as universities, consultancy firms, NGOs, government authorities and municipalities. The project was carried out between 2011 and 2018 with particular focus on the development and dissemination of tools and methods for integrating ecosystem 
services into planning and construction. The typology used within $\mathrm{C} / \mathrm{O}$ City identifies 19 services, and is based on the information activities within the project, which had a wide distribution throughout Sweden. However, though the typology is similar, it differs mainly in relation to cultural and regulating ecosystem services, partly due to the variation in what the different ecosystem services encompass in their labelling.

The typology developed withinC/O City (Keane et al. 2014), and subsequently Boverket (2019b), is largely consistent with the established typology on urban ecosystem services provided by TEEB (2011), as well as the well-cited study by Gómez-Baggethun and Barton (2013), who list ecosystem services for urban planning (see Table 1).

Some ecosystem services are mentioned by all four sources, such as the provisioning service food and the regulating services climate and air quality regulation, moderation of extreme events and pollination. With regard to regulating services, there are slight variations, mainly in relation to water flow and water quality regulation and runoff mitigation, which in Table 1 , have been merged into one rather then distinguish between overlapping denominations of ecosystem services. With regard to cultural ecosystem services, there are rather a lot of discrepancies between the four typologies, although some overlap. For instance, tourism and recreation are not identified as ecosystem services in the two Swedish typologies. With regard to supporting services, Boverket (2019b) and Keane et al. (2014) list several services in addition to those suggested by TEEB, including biodiversity, soil fertility and ecological interconnections, while Gómez-Baggethun and Barton list none (Table 1).
While it is important to adapt typology on urban ecosystem services to local contexts, use of different typologies impedes comparison across case studies and consistency across disciplinary boundaries and associated scales in planning.

\section{Semi-structured interviews}

Semi-structured interviews were conducted with representatives from six Southern Swedish municipalities (see Fig. 1). In a Swedish context, Skåne is considered as being densely populated and the regional administration is considered as being a strong stakeholder that facilitates inter-municipal cooperation, and which has, for example, spearheaded strategies for green urbanisation and agricultural and environmental needs (Region Skåne 2015). The interviews were conducted in six municipalities in Skåne: Malmö, Lund, Ystad, Hässleholm, Tomelilla, and Klippan. The selected municipalities include: two large municipalities ( $>100,000$ inhabitants), two mediumsized municipalities (30000-100,000 inhabitants) and two small municipalities ( $<30,000$ inhabitants). The size criterion was intended to yield a range of municipalities with differences in availability of resources and challenges in relation to the application of the ecosystem services concept (see Yin (2014) for variations of characteristics in sample selection) in order to capture broader tendencies in the implementation. The purpose of the limitation to the regional context of Skåne was to ensure that the municipalities had received offers of similar training and information on ecosystem services, in this case, through organisations such as Region Skåne and the Skåne Association of Local Authorities. The municipalities were selected in consultation with those two organisations, in order to obtain examples from each municipality size
Table 1 Ecosystem service typology developed by TEEB $(2011)^{\mathrm{a}}$, Boverket $(2019 \mathrm{~b})^{\mathrm{b}}$, Keane et al. (2014) ${ }^{\mathrm{c}}$ and GómezBaggethun and Barton (2013) ${ }^{\mathrm{d}}$

\begin{tabular}{|c|c|c|c|}
\hline Provisioning & Regulating & $\begin{array}{l}\text { Habitat or } \\
\text { Supporting }\end{array}$ & Cultural \\
\hline $\begin{array}{l}\text { Food }^{\mathrm{a}, \mathrm{b}, \mathrm{c}, \mathrm{d}} \\
\text { Raw } \\
\text { materials- } \\
\text { a, b, c } \\
\text { Fresh } \\
\quad \text { water }^{\mathrm{a}, \mathrm{b}, \mathrm{c}} \\
\text { Medicine }^{\mathrm{a}} \\
\text { Energy }^{\mathrm{b}, \mathrm{c}}\end{array}$ & $\begin{array}{l}\text { Local climate } \\
\quad \text { regulation/adaptation }{ }^{\mathrm{a}, \mathrm{b}, \mathrm{c}, \mathrm{d}} \\
\text { Air quality regulation } \\
\text { a, b, c, d } \\
\text { Waste-water treatment }^{\mathrm{a}} \\
\text { Water flow and quality regulation }^{\text {and runoff mitigation }}{ }^{\mathrm{b}, \mathrm{c}, \mathrm{d}} \\
\text { Moderation of extreme events } \\
\text { c, d } \\
\text { Carbon sequestration and } \\
\quad \text { storage }^{\mathrm{a}} \\
\text { Erosion prevention }^{\mathrm{a}, \mathrm{b}} \\
\text { Pollination }^{\mathrm{a}, \mathrm{b}, \mathrm{c}, \mathrm{d}} \\
\text { Seed dispersal }^{\mathrm{d}} \\
\text { Biological control }^{\mathrm{a}, \mathrm{b}} \\
\text { Noise regulation }^{\mathrm{b}, \mathrm{c}, \mathrm{d}} \\
\text { Waste treatment }^{\mathrm{d}}\end{array}$ & $\begin{array}{l}\text { Habitats for } \\
\text { species }^{\mathrm{a}, \mathrm{b}, \mathrm{c}} \\
\text { Biodiversity } \\
\text { Maintenance of } \\
\text { genetic } \\
\text { diversity } \\
\text { Soil fertility } \\
\text { Ecological } \\
\text { interconnectio- } \\
\text { ns }{ }^{\mathrm{b}, \mathrm{c}} \\
\text { Natural cycles }\end{array}$ & 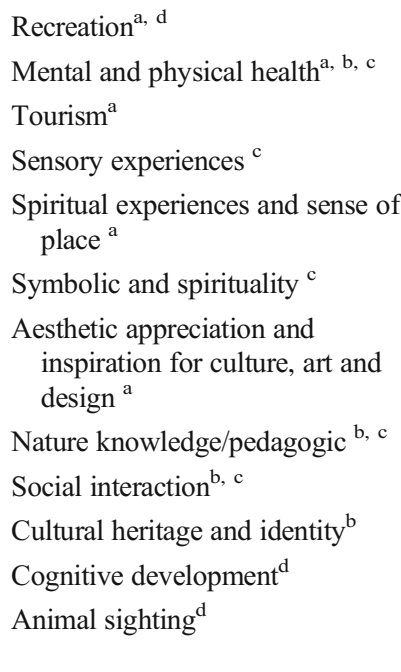 \\
\hline
\end{tabular}




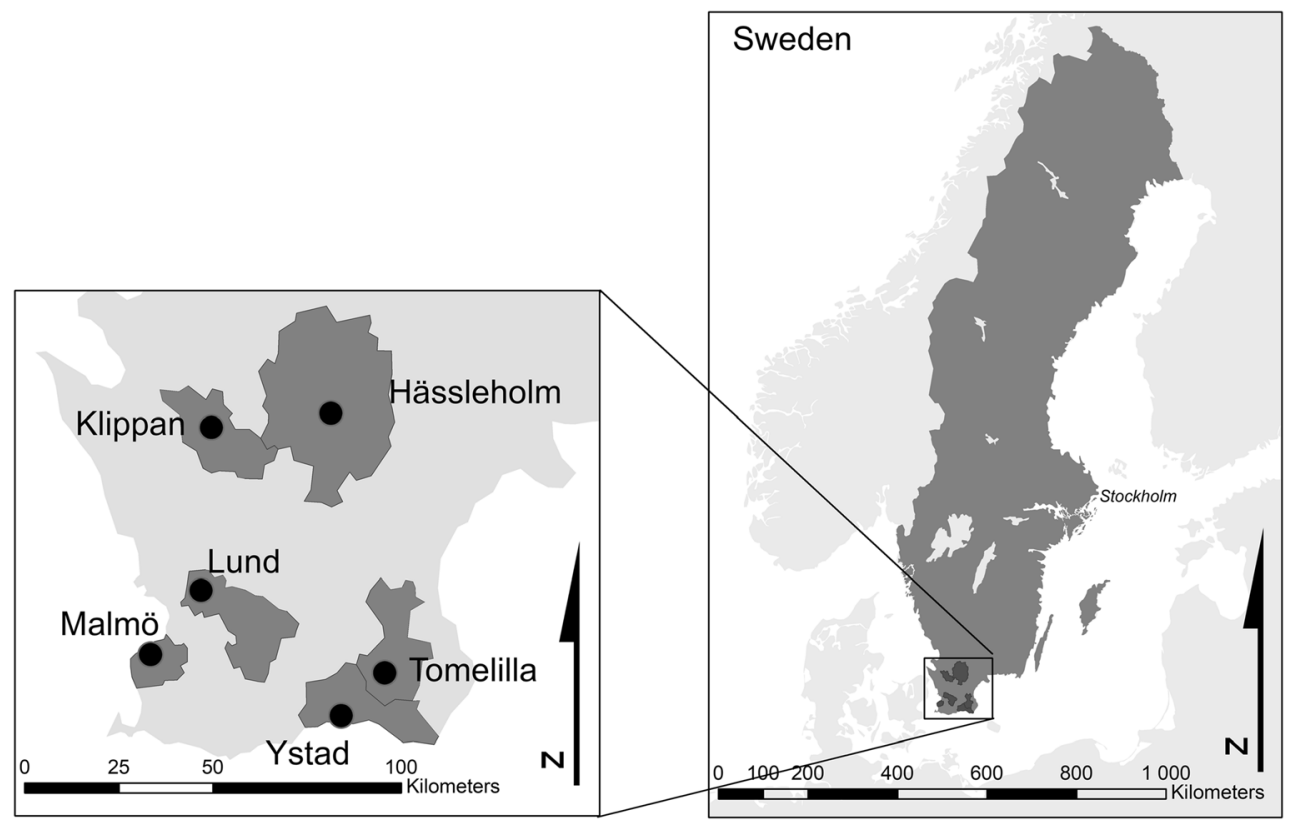

Fig. 1 Location of the six municipalities ecosystem services prioritised in practice in six municipalities in southern Sweden, according to interviewees in this study

category. These consultations took place as part of the Mistra Urban Future's transdisciplinary panel for urban ecosystem services, where key stakeholders from the regional organisation also provided valuable assistance in selecting participants. In the smaller municipalities, this entailed (in some cases only) selecting the stakeholder that worked explicitly with ecosystem services, and in larger municipalities, the cornerstone figures responsible for the implementation process.

Within each municipality, we recruited interviewees through purposeful sampling. The objective was to interview at least two municipal representatives working on a more strategic level and representing both planning and management. This was not possible for all local authorities contacted, e.g. in medium-sized and smaller municipalities there was sometimes only one or two employees available who worked with ecosystem services, and in two cases, the same person was considered to be responsible for handling ecosystem services questions in both planning and management. Immediate interest in participating in the study also varied considerably between municipalities. In dialogue with the selected municipalities and the regional stakeholders, we found a representative sample of interviewees responsible for implementation primarily at strategic level, while only the larger municipalities could provide interviewees with specific responsibility for implementation of ecosystem services at management level. Despite these difficulties in recruiting, both regional and municipal stakeholders confirmed that the final selection represented a good range of municipalities that had actively engaged in implementing an ecosystem service approach in municipal practice. Furthermore, while a larger sample size would have been preferable, the dialogues with the municipalities also confirmed that these were in fact the key stakeholders, and thus the relatively limited number of interviewees working with ecosystem services reflects the current level of implementation. We thus consider the final sample of municipalities and interviewees to have explanatory value (de Vaus 2001), with regard to early implementation approaches for ecosystem services in Southern Sweden.

The semi-structured interviews lasted 60-90 min, and were conducted by $1-2$ of the researchers involved with predefined questions and flexible prompts (Kvale and Brinkmann 2009), allowing for follow-up and response clarification (see Attachment 1). At the start of each interview, definitions and illustrations of 19 key ecosystem services from the Swedish project C/O City (Keane et al. 2014) were presented (see Attachment 2 for illustration used). These were also used in a rational choice component of the interviews, aiming to identify key services, synergies and trade-offs between ecosystem services in the respective municipality. Here, the aim was to urge the interviewees to present the existing and future key themes that each municipality worked with and discussed as ecosystem services. Presented with the list of 19 services, the interviewees were asked to make a rational calculation of their relative importance in their own municipal practice, thus indicating likely pathways for future implementation efforts.

The list was marked, either directly by the interviewee or by the interviewer as per the interviewee's descriptions, with 'priority', 'synergy', and 'conflict' for the relevant services, while follow-up questions ensured concrete descriptions and further nuances. 'Priority' services indicated both existing and needed focal areas. Both are included in the results as 'priority services', as they relate to the relative importance of these services to the municipality according to the perceptions of the practitioners. 
To allow descriptions of both prioritised bundles and interconnections, we did not limit the number of 'priority services' each interviewee could pick. For each interview, we also used printouts from the municipality's comprehensive plans and municipal maps of the central urban areas to stimulate the interviewee to give examples from practice. The interviews were conducted between October and December 2018. Each interview was recorded with the permission of the interviewee in accordance with GDPR regulation and later transcribed for the purpose of data analysis. All interviewees were anonymised to ensure confidentiality of the shared information. ${ }^{1}$

The interviews were analysed by compiling the lists of ecosystem services which had been marked with priority/synergy/conflict in the collaborative note-taking, and key points mentioned were later traced in the transcribed material for nuanced explanations of the provisioning of the key services, as well as multifunctionality, trade-offs and scales of provisions and benefits. In the following analysis, the compiled lists were then used to mark out experienced key priorities, as well as bundles, and conflicts between services across the municipalities in the form of a table.

\section{Review of Swedish publications on urban ecosystem services}

A review was carried out of Swedish publications covering urban ecosystem services with practitioners as the target audience. These publications were identified through the snowball technique, starting with publications by the two main government bodies in charge of ecosystem service implementation in Sweden, i.e. Boverket (National Board of Building, Housing and Planning) and SEPA (Swedish Environmental Protection Agency). These were complemented with publications stemming from well-known Swedish projects on urban ecosystem services (e.g. C/O City) and the lists of references in these publications. In addition, targeted Internet searches were conducted (using the search term "urban ecosystem service" in Swedish) to identify newly published reports. In total, 42 publications published between 2011 and 2018 were identified (see Attachment 3). These publications were broadly categorised as follows: good examples from the practice (12); review publications covering current status in research and practice (16); and guidance/handbooks (14).

All 42 publications were analysed with respect to:

1. Ecosystem services explicitly covered.

2. Whether multifunctionality was covered and specific synergies and trade-offs identified.

\footnotetext{
${ }^{1}$ All were asked to sign a consent form, which was handled in accordance with GDPR requirements. This type of interview study is deemed of common public interest, and does not need approval from an ethical board in Sweden and hence there is no board from which to seek approval.
}

3. The spatial scale and context used for ecosystem services (valuation/mapping, planning, design or maintenance) in practical application.

4. Target audience for the publication

5. If any particular tool was provided

In the following section, the result from the review of the literature for the Swedish practice will be used to complement the results from the interview study, thereby providing additional understanding and a background for the implementation of the ecosystem service concept into municipal practice.

\section{Results}

The field study resulted in six transcribed interviews of 60 90 min covering a broad range of aspects in relation to ecosystem service implementation in municipal planning. The results of the interviews are organized by the following three themes, which also guides the analysis:

1. Focus areas in ecosystem services implementation, with regard to which services were mentioned and given priority as either a current or future focus areas in the interviewees work.

2. Multifunctionality, synergies and trade-offs identified through examples within the interviewees municipality.

3. Spatial scale of ecosystem services application within the interviewees municipality.

The review of the 42 Swedish publications provides a complementary picture of the state of ecosystem service implementation in Swedish municipality practice using the same heading.

\section{Focus areas in ecosystem services implementation}

The interviewees all mentioned 5-8 prioritised services out of the 19 listed, When asked what ecosystem services were the main focus in urban planning and management, the interviewees cited biodiversity most frequently (in 7 out of 8 interviews), followed by climate change adaptation (5) and extreme weather regulation (and specifically stormwater management) (5). ${ }^{2}$ The interviewees described biodiversity as valuable and under threat in urban environments (I2, I3, I4, I5), as having good resonance throughout the municipality as an important priority $\left(\mathrm{I} 4, \mathrm{I}, \mathrm{IF}^{3}\right)$ and as

\footnotetext{
${ }^{2}$ Stormwater management was not a distinct service according to the list provided, but multiple participants identified it as a central part of the regulating service extreme weather regulation.

${ }^{3}$ The letter and numbering refer to the empirical material collected OctoberDecember 2018 and cites where the point was brought up by interview number, where IF stands for Interview focus group
} 
"fundamental" for other services (I1, I3). Climate change adaptation and stormwater management were cited as practical concerns, with the interviewees expressing interest in, for example, finding out how urban ecosystem services could help handle extreme weather such as increased rainfall and stormwater volumes due to climate change (I1, I2, I3). With regard to extreme weather regulation (in particularly stormwater management), they reported that urban ecosystem services already provided useful ways in which to experiment in small and large-scale projects. Examples mentioned ranged from street-side rain gardens with gutter adaptations to feed street plantings (I4, I5), to whole neighbourhood re-developments with park housing and water flow adaptations (I1, I4, I7). Some of the interviewees described the issues and increased interest in ecosystem services-based extreme weather regulation such as stormwater management as "a new theme" (I4, IF), and "a hot topic" (I5). All but one of the services on the list provided to interviewees was considered to be important in at least one interview, but some were clearly of lower priority (Fig. 2).
Regulating services were most frequently mentioned as priorities (24 times), followed by cultural (12 times), supporting (11 times), and provisioning services (8 times) (Fig. 2). One interviewee said that supporting ecosystem services look good in planning, but are rarely prioritised in actual development projects (I7). The only exception was biodiversity, which was mentioned as a priority area by all but one of the interviewees.

\section{Multifunctionality, synergies and trade-offs identified in the interviews}

The interviewees listed many different synergies and relatively fewer trade-offs between services (see Table 2) in direct relationship to green space type that the interviewees came up with to exemplify this. Regulating services appeared most frequently in combination with other services, especially cultural services, such as in efforts to develop good stormwater management solutions in recreational green areas (I1, I4, I7), or to reduce traffic noise, increase pollination and improve aesthetics with urban greenery (I2, I4, I5). Some interviewees mentioned

\section{Prioritized ecosystem service}

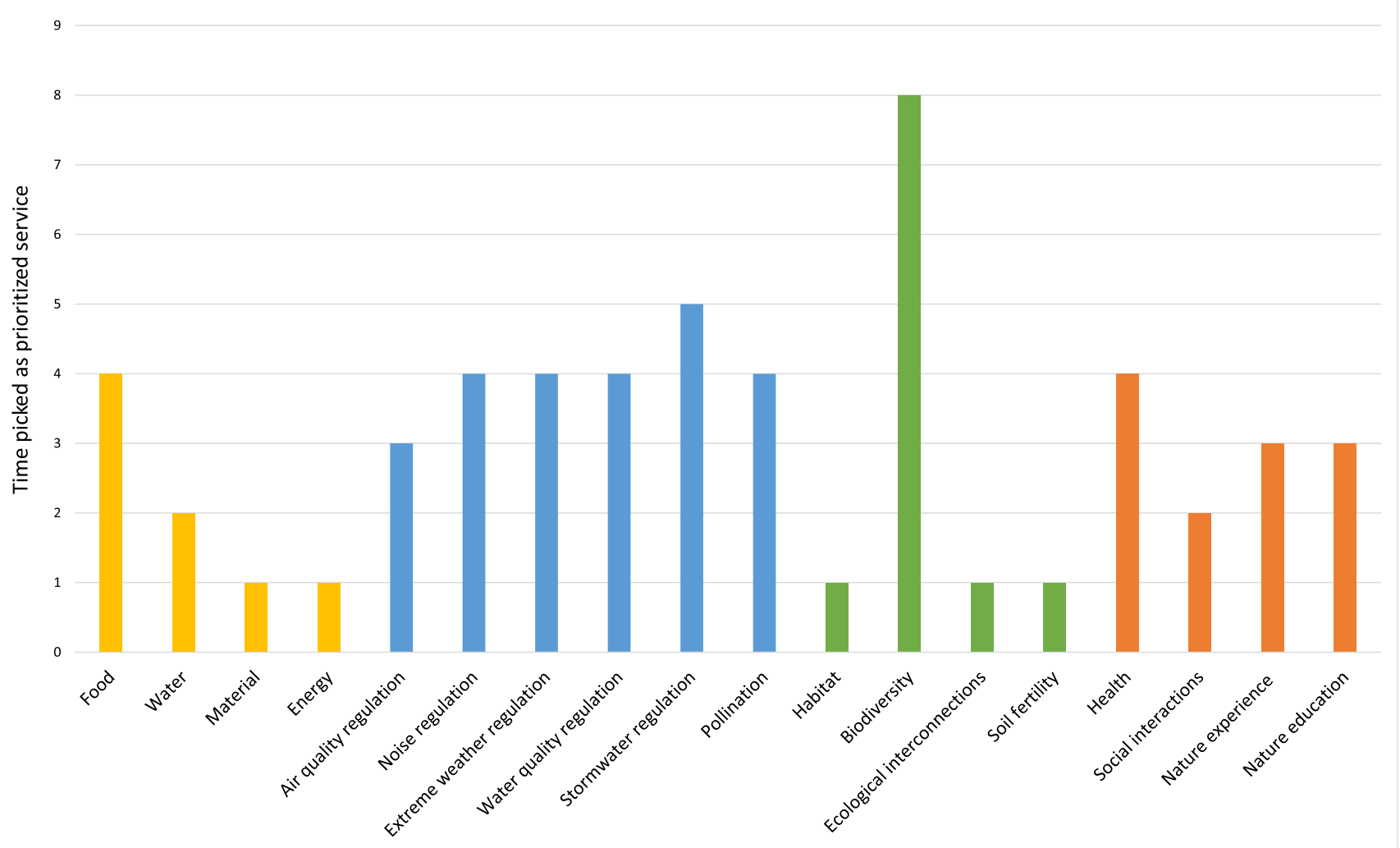

Fig. 2 Prioritised urban ecosystem services as identified by the interviewees in the six municipalities in southern Sweden. The colouring is reflecting the different categories of ecosystem services with yellow $=$ provisioning services, blue $=$ regulating services, green $=$ supporting services and orange $=$ cultural services 
Table 2 The synergies and conflicts between ecosystem services for specific green elements as examples identified by interviewees in this study (C=Conflicting, $\mathrm{S}=$ Synergy)

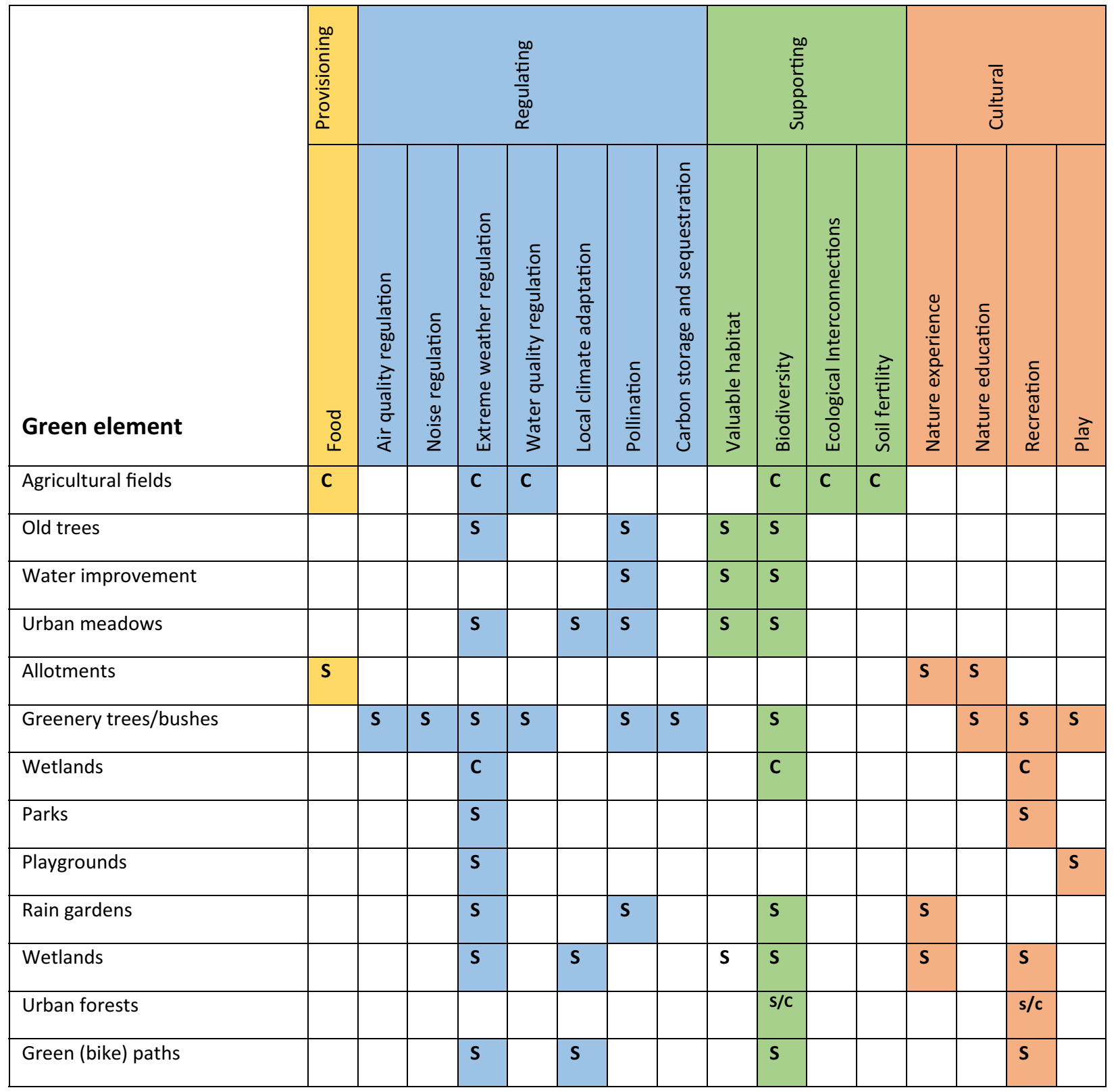

climate change and the growing need to adapt the urban landscape to increased rain or heat intensity (I1, I3, I4). One interviewee mentioned the need for a multifunctional approach: "In the future, we can't just let a street be a street - it will also have to be a stormwater catchment" (I4). The interviewees frequently related concrete problems with biodiversity, pollination, flooding and water quality regulation to the possibility of providing good recreational spaces and better experiences of nature. One interviewee described the recent discussions on multifunctional green spaces as follows: "We talked of a sink which can hold water in the event of major cloudbursts, but which for the rest of the time is part of a park, but lowered. It could also be a playground where in some cases the ground will be completely flooded ... people are scared of flooding, you see" (I7). Two interviewees mentioned new green space developments in the provision of these services in parks and roads and along recreational paths (I4, I6). One described this ongoing effort as follows: "... and this is where extreme weather comes in, along with social factors: we talk a lot about cycling, and when we work with bike paths we often work with stormwater" (I6). Another interviewee explained the increased attention to multifunctionality relating to regulatory services as 
follows: "As for water retention: we have to replace an old bike path with a new one ... it must help with flooding and we must turn the area into a flowery meadow, thus helping with pollination" (I7). Two interviewees explained the shift to integrating multifunctional urban ecosystem services provision more explicitly in planning: “... from now on, we will say: when we look at stormwater management, we will also look at biodiversity and water quality management" (I6).

The interviewees also considered cultural and supporting services to be synergistic, mentioning, for example, the "play value" of schoolyards and public spaces explicitly related to greenery: trees to climb, bushes to play in, among other things, while experiencing and learning about nature (IF, I5, I7). One municipality had recently hired a new outdoor coordinator to improve access to natural areas for various socio-cultural groups, and specifically to work on enhancing the experience and understanding of ecosystems, as well as recreation within the municipality (I4). On the few occasions 'habitats' appeared in the interviews, it was related to the possibility of bettering urban environments for biodiversity and pollination, whether through the protection of old trees, improving aquatic environments or replacing the dominant lawn-mowing practice with annual scything and haymaking in order to improve habitats for insects and other small animals (I3).

The interviewees most frequently described the provisioning services as coming into conflict with cultural and supporting services. On most occasions, this was related to the emphasis on industrial agriculture in regional planning, which was considered to have more political weight than supporting and cultural services (I1, I3, I6). One interviewee gave the example of a common conflict of interest between accessibility and street-side greenery: "A hard surface is much easier to manage, both in terms of accessibility and maintenance costs: it is easier to clean hard surfaces than to weed all the roadsides" (I2). That interviewee also suggested that management and maintenance staff would be more likely to experience conflicts among services (I2).

Food production was not a prioritised urban ecosystem service as such, but appeared in both synergies and conflicts with other services. With regard to synergies, both interviewees in one municipality mentioned a strategy that explicitly related to urban gardening and nature education, attempting to provide citizens with both the knowledge and the skills to grow food on municipal allotments (I1, I3). In terms of conflicts, private management practices in the agricultural landscape and buffer zones around streams leading up to, and out of, the city provided major obstacles to one municipality's ambitions to develop ecological interconnections, protect biodiversity and manage the city's stormwater in a sustainable way: "We hit a wall of wheat. Or of sugar beet. It is very tricky. But interesting!" (I4). Cultural services were also seen as being challenged by the agricultural landscape surrounding the city, with one interviewee citing failed attempts to increase biodiversity as well as accessibility concerns: "The farming sector doesn't want people in the countryside" (I1). Citing further concerns for soil fertility, water quality and biodiversity, one interviewee exclaimed: "I see the big challenge to ecosystem service provision in agriculture" (I7), while also considering the agricultural sector a key collaborator, as "ecosystem service thinking is already present there" (I7). The interviewees also mentioned possible conflicts between supporting and cultural services such as biodiversity and recreation, but considered that they had good solutions available, such as clearly designated recreational areas and path systems that could lead people through the countryside in both an aesthetically and an ecologically meaningful way (IF, I1).

\section{Spatial scale of ecosystem services application in practice, according to interviewees}

The rational choice exercise was followed up by a brief interview on the key systems, documents and plans guiding urban ecosystem services implementation, to identify the scales at which these services were primarily described and planned for (Table 3). While the municipal comprehensive ${ }^{4}$ or green plans were the primary documents describing and guiding implementation, the interviewees chose to also focus on the smaller-scale, but legally binding, detailed plans. ${ }^{5}$ The interviewees described the translation of urban ecosystem service approaches in green and comprehensive plans into detailed plans as being a crucial step for implementation. In some cases, this process had not yet begun, in others it was currently underway and detailed plans with urban ecosystem service approaches and descriptions were waiting to be formally accepted. Of these approaches in detailed planning, several interviewees described the possibility of experimenting with urban ecosystem service approaches in practice (I1, I3, IF), and of ensuring spatial areas for future ecosystem service provision (I1, I4). The systems supporting practical implementation included pioneer projects with i-Tree-inventories, environmental impact reports or checklists for service provision

\footnotetext{
${ }^{4}$ The basic characteristics of the municipality's intended use of land and water areas are presented in the mandatory comprehensive plan (e.g. how the built environment is to be used, developed and preserved; what consideration is to be given to public interests; and what the intention is with regard to how national interests and environmental quality standards are to be served). Indications of national and regional goals, plans and programmes of significance for sustainable development within the municipality should also be presented. (Boverket 2019a. Planning process in Sweden [Online]. https:// www.boverket.se/en/start/building-in-sweden/developer/planning-process/. [Accessed 2019-11-012019])

${ }^{5}$ The detailed development plan regulates the use of land and water areas, as well as what the built environment should look like in a particular area. The plan is generally prepared when new construction is to be carried out in a builtup area. The plan regulates public spaces, development districts and subsequent building permit applications. (ibid)
} 
Table 3 Systems, documents and plans that are mentioned within the interviews to be used in supporting ecosystem service implementation within six municipalities in southern Sweden

\begin{tabular}{|c|c|c|}
\hline $\begin{array}{l}\text { Systems, } \\
\text { documents and } \\
\text { plans }\end{array}$ & $\begin{array}{l}\text { Number of } \\
\text { participants } \\
\text { mentioning } \\
\text { material }\end{array}$ & $\begin{array}{l}\text { Rationale provided by the } \\
\text { interview }\end{array}$ \\
\hline Green Plans & 4 & $\begin{array}{l}\text { Only in effect in some } \\
\text { municipalities, strategic } \\
\text { document for ecosystem } \\
\text { service implementation, } \\
\text { sometimes too separate from } \\
\text { the rest of planning. }\end{array}$ \\
\hline $\begin{array}{l}\text { Detailed plans for } \\
\text { selected areas }\end{array}$ & 4 & $\begin{array}{l}\text { Pioneering ecosystem service } \\
\text { approaches, e.g. to } \\
\text { sustainable stormwater } \\
\text { management in specified } \\
\text { local areas. }\end{array}$ \\
\hline I-Tree & 4 & $\begin{array}{l}\text { Ongoing projects to generate } \\
\text { baseline data on urban trees } \\
\text { and the ecosystem services } \\
\text { they generate. }\end{array}$ \\
\hline $\begin{array}{l}\text { Comprehensive } \\
\text { Plans }\end{array}$ & 3 & $\begin{array}{l}\text { Either implicitly or explicitly } \\
\text { outlining ecosystem service } \\
\text { strategy, needed to secure } \\
\text { surface areas to generate } \\
\text { ecosystem services. }\end{array}$ \\
\hline $\begin{array}{l}\text { Planning and } \\
\text { building } \\
\text { legislation } \\
\text { (PBL) }\end{array}$ & 3 & $\begin{array}{l}\text { Lacking, but needed to support } \\
\text { ecosystem service planning, } \\
\text { for ecosystem services to be } \\
\text { an actual factor that must be } \\
\text { considered in specific } \\
\text { development projects, } \\
\text { needed to demand } \\
\text { generation of ecosystem } \\
\text { services on private land. }\end{array}$ \\
\hline $\begin{array}{l}\text { Expanded } \\
\text { comprehensive } \\
\text { plans }\end{array}$ & 2 & $\begin{array}{l}\text { Further specifies the approach } \\
\text { to generating ecosystem } \\
\text { services on specific areas. }\end{array}$ \\
\hline $\begin{array}{l}\text { Ecosystem service } \\
\text { compensation } \\
\text { mechanism }\end{array}$ & 2 & $\begin{array}{l}\text { Needed to safeguard the loss of } \\
\text { ecosystem services during } \\
\text { construction and } \\
\text { development projects, } \\
\text { baseline data often needed } \\
\text { but expensive and complex } \\
\text { to generate within } \\
\text { municipalities. }\end{array}$ \\
\hline $\begin{array}{l}\text { Environmental } \\
\text { impact reports }\end{array}$ & 2 & $\begin{array}{l}\text { Named as a good potential } \\
\text { place to safeguard } \\
\text { ecosystem service provision } \\
\text { during urban development, } \\
\text { but not yet being done. }\end{array}$ \\
\hline
\end{tabular}

for new developments (I2, I3, I4, IF). The interviewees mentioned better support in planning and building legislation, compensation mechanisms for lost services, and better inventories of existing urban ecosystem services as ways to aid implementation.

\section{Ecosystem services listed in publications}

A large proportion (44\%) of the publications reviewed treated ecosystem services as a concept and did not discuss specific groups, let alone individual services (see Fig. 3). Of those that did focus on type of ecosystem service, regulating services dominated and were covered in $47 \%$ of the publications reviewed, while cultural ecosystem services were covered in $25 \%$. Provisioning and supporting services were covered in only around $10 \%$ of the publications. The most frequently mentioned regulating services were extreme weather regulation (20 mentions), local climate regulation (18) and pollination (15) (Fig. 3). The most frequently mentioned cultural services were recreation (16 mentions) and health (13). Among the supporting services, food was mentioned by 11 publications but biodiversity was the most frequently mentioned of the supporting services, covered in 16 of the 42 publications.

\section{Multifunctionality and synergies between ecosystem services}

Of the 42 publications, 20 specifically mentioned multifunctionality in relation to ecosystem services, although to varying degrees. Several of these publications emphasised the need to view ecosystem services as part of systems thinking (e.g. Dahl et al. 2017) and the dependency of one ecosystem service on other ecosystem services for its production. For instance, the cultural service of nature education is dependent on the supporting services of biodiversity and habitat (e.g. Seffel et al. 2014). Some synergies were seen as more general, such as the synergy between the supporting services of biodiversity and valuable habitat, and cultural services such as sensory experience and health (e.g. Andersson et al. 2012; Bokalders and Block 2014). Table 4 summarises the types of synergies between ecosystem services for specific elements identified in four publications (e.g. Andersson et al. 2017; Bokalders and Block 2014; C/O City 2017a; Dahl et al. 2017), and could be seen as examples of where synergies are currently recognised. None of the publications reviewed outlined explicitly any trade-offs between ecosystem services. The most recognised combinations across different types of green elements included local climate regulation, extreme weather regulation, pollination, valuable habitat, biodiversity, recreation and sensory experience (Table 4). Few of the publications mentioned any provisioning services when discussing multifunctionality for specific green elements. Several of the guidelines mentioned specific tools that could support work on multifunctionality. The tool described as 'Green Area Factor for Public Land' was developed within the $\mathrm{C} / \mathrm{O}$ City project and basically scores an area according to amount of different ecosystem services delivered and the quality of those services (C/O City 2017b). An area receives a higher score if there is a balanced distribution of ecosystem services in all four categories, i.e. if the area 


\section{Distribution of ecosystem service coverage}

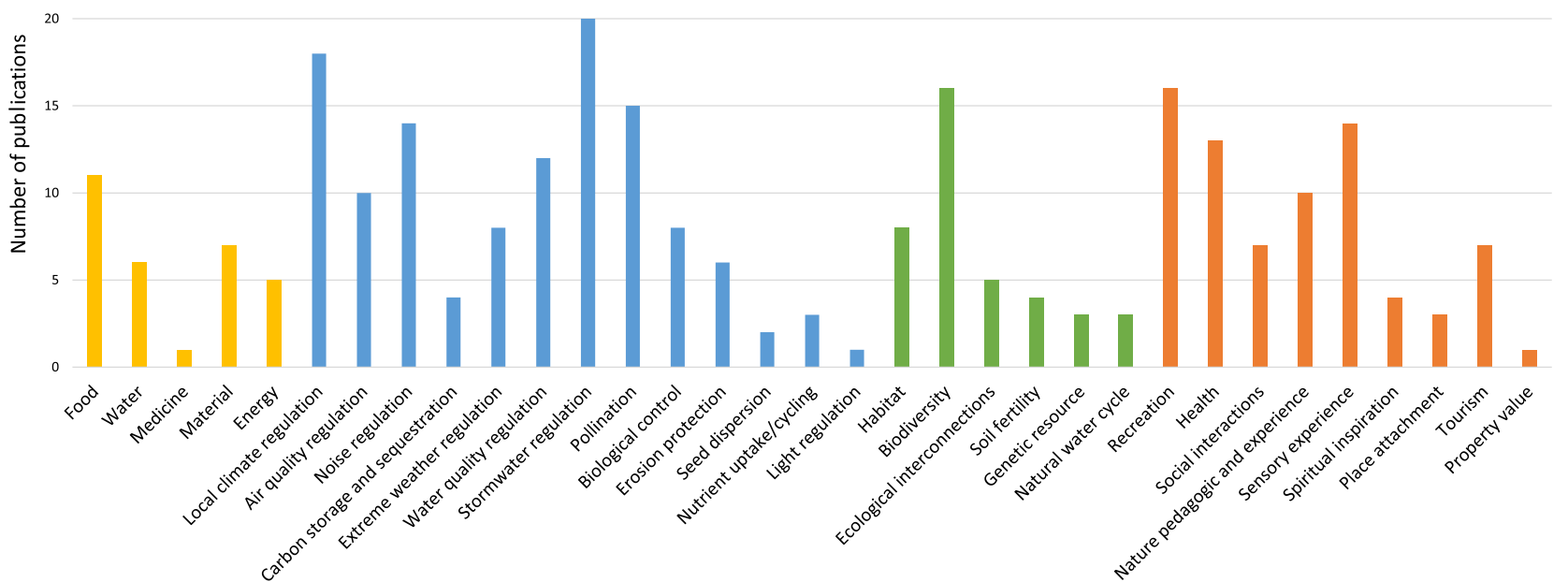

Fig. 3 Distribution of individual urban ecosystem services coverage in the 42 Swedish publications reviewed in this study. The ecosystem services listed are based on the publications listing and hence this differs from the ecosystem services identified by the municipality. The

is multifunctional. However, the publications provided no discussion with regard to which ecosystem services could be combined and where potential trade-offs exist. The Green Area colouring is reflecting the different categories of ecosystem services with yellow $=$ provisioning services, blue $=$ regulating services, green $=$ supporting services and orange $=$ cultural services

Factor tool emphasises the need to look at different solutions simultaneously in order to identify the solution delivering the services required and the synergistic production of other types

Table 4 Synergies between ecosystem services for specific urban green elements in Sweden

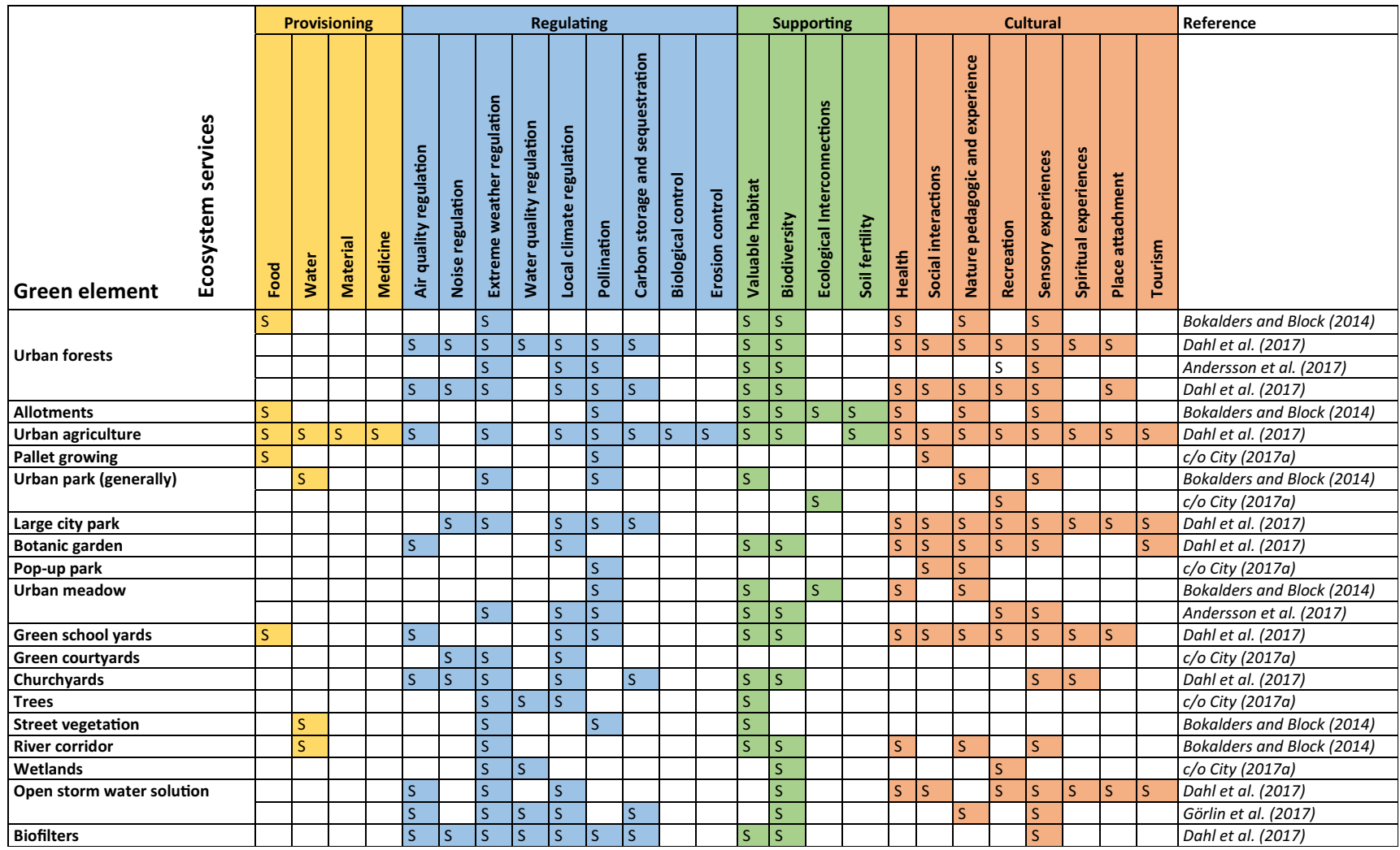


of ecosystem services (Van Noord and Winkler 2014). Within the BiodiverCity project, the focus was on different types of nature-based solutions for the dense city, particularly for increasing biodiversity, but also for discussing how these solutions could be designed to offer the synergistic production of other ecosystem services (Andersson et al. 2017).

\section{Scale and context for ecosystem services application in the publications reviewed}

In the publications, the concept of ecosystem services was applied on multiple scales, ranging from the specific object (tree or park) up to the full municipality and regional level (see Fig. 4 for distribution of publications according to scale of application). Most of the publications applied the concept of ecosystem services on at least two scales (e.g. Boverket 2017; Dahl et al. 2017; Granath et al. 2012), and hence these publications were categorised as 'multiple-scale'. Several of the publications categorised as applying ecosystem services at multiple scales were practical examples linking the application of ecosystem services to several types of plan processes (for practical examples, see Hilding-Rydevik and Blicharska (2016)).

Of the publications dealing with ecosystem services at 'single-scale' level, these mostly focused on the neighbourhood or block level, which corresponds to the legally binding detailed plan (e.g. Andersson-Sköld et al. 2018b; Malmaeus et al. 2015; van Noord and Winkler 2014). There were also examples of working on a municipal level and linking the application to the comprehensive plan (e.g. Ask et al. 2015; Hamrén et al. 2016). Only a few of the publications reviewed focused on specific objects or solutions. These included green roofs
(Capener et al. 2017) and nature-based solutions (Andersson et al. 2017).

In some of the publications, there was no real application of the scale concept, and hence these publications were categorised as 'undefined'. These included a research overview on the relationship between biodiversity and ecosystem services (Formas 2015) as well as more conceptual publications arguing the case for the application of the ecosystem services concept (e.g. Görlin et al. 2017).

The target audience for most of the publications reviewed consisted of municipalities or other stakeholders in urban planning and development, with the focus on how ecosystem services could be integrated into the physical planning process (e.g.C/O City 2017c; Colding et al. 2013) (see Attachment Table A1). Only a few of the publications focused specifically on design and construction in order to achieve good ecosystem service delivery (e.g. Bokalders and Block 2014; Eriksson et al. 2016; Keane et al. 2014). Some publications discussed the application of the ecosystem concept throughout the full chain of planning, design, construction and maintenance (e.g. Boverket 2017; C/O City, 2017a; Colding et al. 2013; Dahl et al. 2017; Hellström et al. 2016; Jansson et al. 2013), but while multiple scales and contexts were represented, some publications lacked sufficient consideration for scale/multiple contexts.

\section{Discussion}

In this study, we interviewed individuals working with strategic planning or management within the six selected municipalities

\section{Distribution of scale covered}

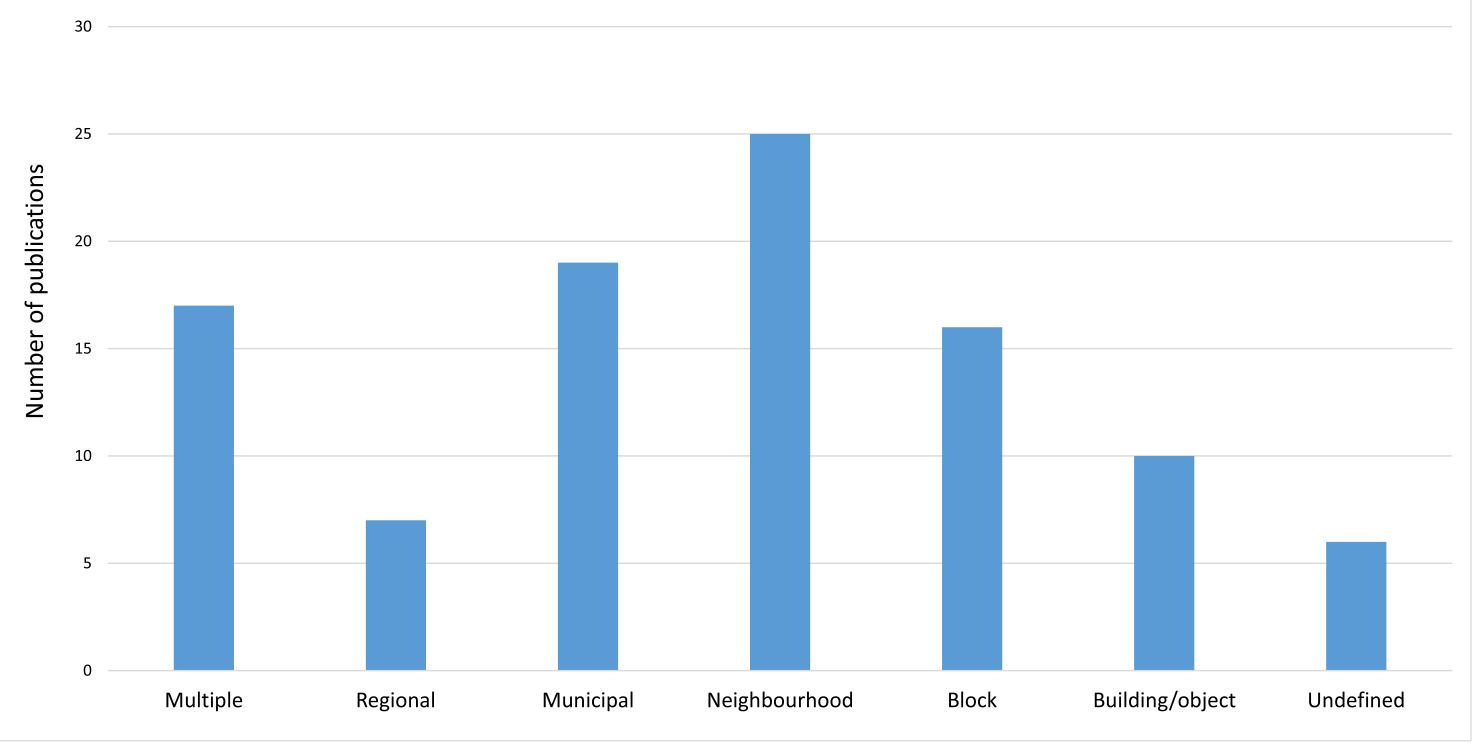

Fig. 4 Distribution of spatial scale in relation to ecosystem services covered in the Swedish publications reviewed in this study. Multiple means that several scales were used in the publications 
in order to assess the broader implementation and adaptation of the urban ecosystem services concept. We found that the guidelines published up to 2018 particularly targeted municipal stakeholders involved in spatial planning processes (e.g. C/ OCity 2017c; Colding et al. 2013), but paid less attention to the management and maintenance side of urban ecosystem services delivery.

\section{Ecosystem services in focus}

The interviews and review of guidelines revealed that a large amount of typologies were used in relation to ecosystem services, with these being inconsistent with the visual prompt (Keane et al. 2014) used for the interviews. The interviews revealed that biodiversity was seen as a key service for addressing urgent problems/shortcomings in urban development and resonated with the existing discourse in governance. Regulating services were the most prevalent, and implementation through problem solving was the main way of working with ecosystem services within the municipalities. In the six municipalities, supporting (with the exception of biodiversity) and provisioning services appeared to be generally less frequently implemented in current urban planning and management. Recent findings on governance challenges to the implementation of ecosystem services in the same municipalities studied here, indicate that political priority is often lacking, which in turn could explain the focus by practitioners on politically salient regulatory services such as climate adaptation and extreme weather regulation (e.g. stormwater management) (Hagemann et al. 2020).

The focus on biodiversity within the planning practice was also evident in the study by Hansen et al. (2015). Their study of planning documents from 5 cities (2 US and 3 European) showed that habitat for species was the most frequent ecosystem service, as well as a service that was elaborated on. Similarly to our result, Hansen et al. (2015) also found that regulatory services were frequently mentioned, though they differed in the respect that some of the cultural services were among the individually most frequently mentioned ecosystem services. The interviewees in our study differed from the Hansen et al. (2015) study, emphasising the complementary provision of cultural services when addressing concrete problems (such as climate adaptation and extreme weather regulation), rather than viewing cultural services as the prime ecosystem service. The guideline publications differed slightly in focus here, with regard to their dominance of regulatory services, with the most common services being storm water regulation (19), local climate regulation (16) and pollination (15). This mirrors findings from reviews on urban ecosystem service research, where the focus has clearly been on regulatory services (e.g. Charoenkit and Piyathamrongchai 2019; Haase et al. 2014; Keeler et al. 2019; Luederitz et al. 2015). However, it is unclear as to whether this similarity in distribution reflects the translation of research into practice or whether it is in response to current policy focus on climate adaption and resilience.

Neither the interviews nor the published guidelines mentioned provisioning services such as food provision to any higher degree. In the study by Hansen et al. (2015), food supply was the seventh most frequently mentioned ecosystem service, and provisioning services as a group were covered in $43 \%$ of studies reviewed by Charoenkit and Piyathamrongchai (2019). In Sweden, agricultural production is not legally regulated within spatial planning and hence agricultural land is only dealt with in relation to exploitation (Granvik et al. 2015) which might explain the low focus on food provision in this study.

\section{Multifunctionality, synergies and trade-offs between ecosystem services}

The capacity of the ecosystem services concept to promote multifunctionality was a very strong theme in interviews and in the Swedish publications reviewed, confirming current research discourses on Green Infrastructure planning (Hansen and Pauleit, 2014; Wang and Banzhaf, 2018). Synergies were a popular theme among the interviewees who listed many possible combinations and who emphasised that regulatory and cultural ecosystem services could be combined, also with supporting ecosystem services. In both the interviews and the existing guidelines, there was general consensus on synergies between the supporting services of biodiversity and valuable habitat and cultural services such as sensory experience and health. The Swedish publications reviewed considered that a combination of regulatory, supporting and cultural ecosystem services could be obtained with most urban green elements. The interviews echoed these possibilities for regulatory/ supporting/cultural synergies, often in experimentation or tests and where concrete problems needed to be solved - playing up the strengths of the thinking involved in urban ecosystem services as well as showing the implementation of urban ecosystem services as being under negotiation, rather than part of fully formed governance approaches. In the reviews by Chaorenkit and Piyathamrongchai (2019) and Lee and Lautenbach (2016), it was similarly found that synergies were often identified between regulating and cultural ecosystem services.

By contrast, the trade-offs were less clearly expressed in interviews and in the Swedish publications reviewed. The interviewees generally recognised a trade-off between biodiversity and recreation. The lack of recognition of other trade-offs could be partly due to cultural ecosystem services trade-offs being undervalued, as they are subjective and difficult to quantify (Daniel et al. 2012). In the review by Lee and Lautenbach (2016), trade-offs were mostly found between regulating and provisioning services. The low occurrence of provisioning services within both the interviews and publications suggests that more established trade-offs were never identified. Haase et al. 
(2014) stressed the need to integrate the assessment of multiple urban ecosystem services into spatial planning and strategic management in order to enable informed decisions. This explicitly requires trade-offs and synergies between ecosystem services, so as to highlight conflicts and win-win situations. While there was awareness and implicit understanding of potential win-win situations among the municipal representatives interviewed here, few tools seemed to be used to fully reveal these synergies. Tools such as Green Area Factor, which is designed to fit the scale and format of detailed municipal plans (c/o City 2017b), could provide support for the implementation of urban ecosystem services as well as highlight synergies between different ecosystem service types, and thereby partly address the expressed lack of tools to match the spatial scale of planning as described among others by Haase et al. (2014).

\section{Spatial scale and governance context}

The target audience for most of the Swedish publications consisted of stakeholders in municipal planning, and the focus was on the integration of the urban ecosystem services concept into the planning process on multiple scales. From the interviews it was clear that, until recently, work on urban ecosystem services has focused on the municipal scale, through comprehensive plans and green plans. On the strategic municipal level, the interviewees reported a lack of data on the potential supply of urban ecosystem services that could aid the implementation of strategies. A number of the publications reviewed concentrated on the mapping and valuation of urban ecosystem services, and this is also an area covered in current research on various approaches for surveying the supply of ecosystem services (Haase et al. 2014). This provides an important step towards being able to carry out the balanced assessments of blue-green alternatives in relation to grey infrastructure solutions (Saarikoski et al. 2018). However, the question here is whether the tools and approaches presented in the current guidelines constitute the sought after userfriendly method that could guide planners in the assessment of ecosystem services in the strategic planning and management of the green resources (Hansen et al. 2015).

However, the holistic approaches that the ecosystem service concept provides constitute the key aspect that could be integrated into and coordinated across different planning instruments, as suggested by Hansen et al. (2015). This could either be done through its use as a supporting concept for planning and policymaking, or as a tool supplementing existing practice (Hansen et al. 2019).

\section{Limitations and transferability of results}

The rational choice of prioritised ecosystem services, as well as the synergies between them within practice as presented in this study, is based on a small sample of local authorities in
Sweden. It could be argued that other municipalities might have different choices and experiences, just as different trajectories might follow from this (still quite early) stage. The current findings, however, point to an immediate usefulness and complementarity (of 'problem-solving ES', multifunctional perspectives, etc.) with existing municipal practice.

Our results are also reflected in studies from other contexts (e.g. Hansen et al. 2019), highlighting the interest in biodiversity but otherwise with a focus on regulatory services and a limited focus on trade-offs between ecosystem services within practice. Through the complementary review of guidelines that address local authorities throughout Sweden, the experiences of the focus on regulatory services as well as cultural services are also confirmed. The municipalities could thereby be seen as addressing the ecosystem services that need to be produced within the city in order to support sustainable cities and communities. It could therefore be argued that the focus on exploring trade-offs in an urban context should be on those between regulating and cultural ecosystem services on the scale levels applicable to urban planning. Excluding biodiversity, supporting ecosystem services (such as habitat provision) received a low priority despite them forming the basis for functional ecosystems (e.g. Peterson et al. 1998), and these could not be excluded, despite the lower priority received in practice as shown in this study.

\section{Conclusions}

This study evaluated the current discourse on urban ecosystem services within Swedish municipalities with regard to key ecosystem services, views on synergies and trade-offs between ecosystem services and the implementation of the concept in planning and management. The results in this study showed that regulatory services are the main focus in Swedish municipalities and in Swedish publications available to practitioners. Consequently, the concept is generally implemented through problem solving, seeking multifunctionality, and winwin situations in ecosystem service supply. These findings are a novel contribution to the growing body of work exploring how the concept of urban ecosystem services is adapted and used in practice across multiple contexts.

Supplementary Information The online version contains supplementary material available at https://doi.org/10.1007/s11252-021-01113-7.

Material availability The transcript of the interviews is stored securely at the university and is available on request.

Funding Open access funding provided by Swedish University of Agricultural Sciences. This research was supported by Mistra Urban Futures as a part of the expert panel on Urban Ecosystem Services of the Skåne Local Interaction Platform (SKLIP) in southern Sweden. 


\section{Declarations}

Ethics approval The research follows the guidelines for good research ethics as recommended in booklet 'Good research practice, Swedish research council 2017' where it is emphasized that the participants should be informed that they are participating in a research project. According to the Swedish ethical guidelines ('Good research practice, Swedish research council 3:2017), a research project should be reviewed by an ethics review board if any of the following conditions exist. Namely, if the project (A) - entails physical encroachment on the research subject, will be conducted using a method aiming to affect the research subject physically or psychologically, - carries an obvious risk of physical or psychological harm to the research subject, or - entails studies on biological material that can be traced to specific individuals. A research project should also be reviewed if it (B) entails the handling of sensitive personal data according to $13 \S$ of the Personal Data Act (SFS 1998:204), including information on race, ethnic origin, political views or religious conviction or personal data according to $21 \S$ of the Personal Data Act, including information on judgements in criminal cases. Since none of the listed conditions applied to this project is has not been submitted to an ethical review board.

Consent Before the interview each respondent signed a consent form developed based on the ethical guidance of SLU. The interviewees were before signing the document informed that their answers will be used in a research project, that their contribution was voluntarily, that their data will be treated confidentially and stored securely.

\section{Conflict of interest There is no conflict of interest.}

Open Access This article is licensed under a Creative Commons Attribution 4.0 International License, which permits use, sharing, adaptation, distribution and reproduction in any medium or format, as long as you give appropriate credit to the original author(s) and the source, provide a link to the Creative Commons licence, and indicate if changes were made. The images or other third party material in this article are included in the article's Creative Commons licence, unless indicated otherwise in a credit line to the material. If material is not included in the article's Creative Commons licence and your intended use is not permitted by statutory regulation or exceeds the permitted use, you will need to obtain permission directly from the copyright holder. To view a copy of this licence, visit http://creativecommons.org/licenses/by/4.0/.

\section{References}

Andersson-Sköld Y, klingberg J, Gunnarsson B, Cullinane K, Gustafsson I, Hedblom M, Knez I, Lindberg F, Ode Sang Å, Pleijel H, Thorsson P, Thorsson S (2018a) A framework for assessing urban greenery's effects and valuing its ecosystem services. J Environ Manag 205: 274-285

Andersson-Sköld Y, Klingberg J, Gunnarsson B, Thorsson S (2018b) Metod för bedömning och värdering av ekosystemtjänster i staden (VEKST), Handbok version 1.0. University of Gothenburg, Gothenburg

Andersson J, Fransson A-M, Kruuse A, Poppius U, Nordius Stålhamre J, Malmberg J, Block J (2017) Biologisk mångfald i den täta staden tips och erfarenheter kring gröna lösningar. BiodiverCity, Malmö

Andersson, J., Sandberg, J., Näsström, H. 2012. När, vad och hur - Svaga samband i Stockholmregionens gröna kilar. Rapport 5:2012. Stockholm: Tillväxt, miljö och regionplanering

Ask K, Möllegård J, Hamrén U, Seffel A, Sjösten F, Troglio EK, Wågström A (2015) Kartläggning av ekosystemtjänster i Upplands
Väsby kommun. Upplands Väsby kommun and Ekologigruppen, Upplands Väsby

Beery T, Stålhammar S, Jönsson KI, Wamsler C, Bramryd T, Brink E, Ekelund N, Johansson M, Palo T, Schubert P (2016) Perceptions of the ecosystem services concept: opportunities and challenges in the Swedish municipal context. Ecosystem Services 17:123-130

Bokalders V, Block ME (2014) Urbana ekosystemtjänster: Låt naturen göra jobbet. Stockholm: c/o City

Boverket (2017) Naturens tjänster i staden - till nytta och glädje! Swedish National Board of Housing, Building and Planning, Karlskrona

Boverket (2019a) Planning process in Sweden [Online]. https://www. boverket.se/en/start/building-in-sweden/developer/planningprocess/. Accessed 11-01 2019

Boverket (2019b) Rumsliga förusättningar för ekosystemtjänster i den byggda miljön. Swedish National Board for Housing, Building and Planning, Karlskrona, Sweden

C/O City (2017a) Gröna lösningar ger levande städer [Online]. https:// www.cocity.se/wp-content/uploads/2018/06/grona_losningar levande_stader-1.pdf. Accessed 15 Feb 2019

C/O City (2017b) Grönytefaktor för allmän platsmark:2.0 [Online]. https://www.cocity.se/wp-content/uploads/2018/06/gyf-ap-20manual_lagupplost.pdf. Accessed 15 Feb 2019

C/O City (2017c) Naturen i staden - tips och råd för fler ekosytemtjänster [Online]. https://www.cocity.se/wpcontent/uploads/2018/06/ naturen_i_staden_tips_rad.pdf. 15 Feb 2019

Capener CM, Petterson Skog A, Emilsson T, Malmberg J, Jägerhök T, Edwards Y, Månsson H (2017) Grönatakhandboken - Vägledning [Online]. https://gronatakhandboken.se/. Accessed 15 Feb 2019

Charoenkit S, Piyathamrongchai K (2019) A review of urban green spaces multifunctionality assessment: A way forward for a standardized assessment and comparability. Ecological Indicators 107

Colding J, Marcus L, Barthel S, Andersson E, Gren Å, Borgström S (2013) Ekosystemtjänster i Stockholmsregionen. Report 2013:3. Stockholm: Tillväxt, miljö och regionplanering

Dahl C, Jergmo F, Klein H, Nilsson G, Olsson T, Rasmusson A, Bergquist D, Emilsson T, Fransson AM, Randrup TB, Andersson UE (2017) Ekosystemtjänsternas bidrag till god urban livsmiljö. Stockholm

Daniel TC, Muhar A, Arnberger A, Aznar O, Boyd JW, Chan KMA, Costanza R, Elmqvist T, Flint CG, Gobster PH, Grêt-Regamey A, Lave R, Muhar S, Penker M, Ribe RG, Schauppenlehner T, Sikor T, Soloviy I, Spierenburg M, Taczanowska K, Tam J, Von Der Dunk A (2012) Contributions of cultural services to the ecosystem services agenda. Proc Natl Acad Sci U S A 109:8812-8819

DE Groot RS, Alkemade R, Braat L, Hein L, Willemen L (2010) Challenges in integrating the concept of ecosystem services and values in landscape planning, management and decision making. Ecol Complex 7(3):260-272

De Vaus D (2001) Research design in social research. Sage, London

Eriksson L, Haeggman M, Hård AF, Segerstad L, Kjellson K, Schön M (2016) Resilienta villastäder. Albaeco och Kod arkitekter [Online]. https://kodarkitekter.se/projekt/resilienta-villastader/. Accessed 15 Feb 2019

Formas (2015) Analys av forskning om biologisk mångfald och ekosystemtjänster. Formas and Swedish Environmental Protection Agency

Gómez-Baggethun E, Barton DN (2013) Classifying and valuing ecosystem services for urban planning. Ecol Econ 86:235-245

Görlin K, Persson A, Jönsson-Belyazid U, Hansson J, Soutukorva A (2017) Argument för mer ekosystemtjänster. Report 2017:6736. Stockholm

Granath F, Blom G, Östergård H, Andersson J, Inghe O, Hagbarth U, Ivarsson M, Hemmingsson M, Siira U (2012) Sammanställd information om Ekosystemtjänster. Report NV-00841-12. Stockholm: Swedish Environmental Protection Agency and Swedish Agency for Marine and Water Management 
Granvik M, Jacobsson T, Blix-Germundsson L, Larsson A (2015) The approach of Swedish municipalities to the preservation of agricultural land in a planning context. Int J Agric Resour Gov Ecol 11: 190-204

Haase D, Larondelle N, Andersson E, Artmann M, Borgström S, Breuste J, Gomez-Baggethun E, Gren Å, Hamstead Z, Hansen R (2014) A quantitative review of urban ecosystem service assessments: concepts, models, and implementation. Ambio 43:413-433

Hagemann FA, Randrup TB, Sang ÅO (2020) Challenges to implementing the urban ecosystem service concept in green infrastructure planning: a view from practitioners in Swedish municipalities. Socio-Ecol Pract Res 2:283-296

Hamrén U, Ask K, Brunsell L, Seffe A (2016) Utvecklingsplan för ekosystemtjänster i Upplands Väsby kommun. Upplands Väsby kommun and Ekologigruppen, Upplands Väsby

Hansen R, Pauleit S (2014) From multifunctionality to multiple ecosystem services? A conceptual framework for multifunctionality in green infrastructure planning for urban areas. Ambio 43:516-529

Hansen R, Frantzeskaki N, Mcphearson T, Rall E, Kabisch N, Kaczorowska A, Kain J-H, Artmann M, Pauleit S (2015) The uptake of the ecosystem services concept in planning discourses of European and American cities. Ecosystem Services 12:228-246

Hansen R, Olafsson AS, Van Der JAGT AP, Rall E, Pauleit S (2019) Planning multifunctional green infrastructure for compact cities: what is the state of practice? Ecol Indic 96:99-110

Hellström C, Månsson J, Härdgård C (2016) Ekosystemtjänster i planoch bygglagen. Delphi and Swedish National Board of Housing, Building and Planning, Karlskrona

Hilding-Rydevik, T., Blicharska, M. 2016. Ekosystemtjänster i praktiken. Report 2016:6724. Stockholm

Hölting L, Beckmann M, Volk M, Cord AF (2019) Multifunctionality assessments-more than assessing multiple ecosystem functions and services? A quantitative literature review. Ecol Indic 103:226-235

Jaligot R, Chenal J (2019) Integration of ecosystem services in regional spatial plans in Western Switzerland. Sustainability 11:313

Jansson M, Persson A, Östman L (2013) Hela staden - argument för en grönblå stadsbyggnad. Report Stad \& Land 183. Movium, Alnarp

Keane Å, Stenkula U, Wijkmark J, Johansson E, Philipson K, Hård AF, Segerstad L (2014) Ekosystemtjänster i stadsplanering - en vägledning [Online]. https:/www.cocity.se/wp-content/uploads/ 2018/06/ekosystemtjanster-i-stadsplanering-en-vagledning-co-city. pdf. Accessed 15 Feb 2019

Keeler BL, Hamel P, Mcphearson T, Hamann MH, Donahue ML, Prado KAM, Arkema KK, Bratman GN, Brauman KA, Finlay JC, Guerry AD, HOBBIE SE, Johnson JA, Macdonald GK, Mcdonald RI, Nerisky N, Wood SA (2019) Social-ecological and technological factors moderate the value of urban nature. Nature Sustainability 2:29-38

Kotzeva, M. M., \& Brandmüller, T. (Eds.). 2016. Urban Europe: statistics on cities, towns and suburbs. Publications office of the European Union

Kvale S, Brinkmann S (2009) InterViews: learning the craft of qualitative research interviewing, 2nd edn. Sage Publications Inc., Thousand Oaks

La Rosa D (2019) Why is the inclusion of the ecosystem services concept in urban planning so limited? A knowledge implementation and impact analysis of the Italian urban plans. Socio-Ecological Practice Research:1-9

Lee H, Lautenbach S (2016) A quantitative review of relationships between ecosystem services. Ecol Indic 66:340-351

Luederitz C, Brink E, Gralla F, Hermelingmeier V, Meyer M, Niven L, Panzer L, Partelow S, Rau AL, Sasaki R, Abson DJ, LANG DJ, Wamsler C, Von Wehrden H (2015) A review of urban ecosystem services: six key challenges for future research. Ecosystem Services 14:98-112

Malmaeus M, Hansen K, Hasselström L, Lindblom E, Norén K, Soutukorva Å, Söderqvist T, Tegeback A (2015) Ekosystemtjänster i miljökonsekvensbeskrivningar och samhällsekonomiska konsekvensanalyser. Report B2248. Stockholm

Mascarenhas A, Ramos TB, Haase D, Santos R (2015) Ecosystem services in spatial planning and strategic environmental assessment-a european and portuguese profle. Land Use Policy 48:158-169

Peterson G, Allen CR, Holling CS (1998) Ecological resilience, biodiversity, and scale. Ecosystems 1(1):6-18

Rall EL, Kabisch N, Hansen RA (2015) Comparative exploration of uptake and potential application of ecosystem services in urban planning. Ecosystem Services 16:230-242

Region Skåne (2015) Ett Grönare Skåne - Hur fysisk planering kan möta Skånes miljöutmaningar., Region Skåne - Enheten för fysisk planering

Saarikoski H, Primmer E, Saarela SR, Antunes P, Aszalós R, Baró F, Berry P, Blanko GG, Goméz-Baggethun E, Carvalho L, Dick J, Idunford R, Hanzu M, Harrison PA, Izakovicova Z, Kertész M, Kopperoinen L, Köhler B, Langemeyer J, Lapola D, Liquette C, Luque S, Mederly P, Niemelä J, Palomo I, Pastur GM, Peri PL, Preda E, Priess JA, Santos R, Schleyer C, Turkelboom F, Vadineanu A, Verheyden W, Vikström S, YOUNG J (2018) Institutional challenges in putting ecosystem service knowledge in practice. Ecosystem Services 29:579-598

Schubert P, Ekelund NGA, Beery TH, Wamsler C, Jönsson KI, Roth A, Stålhammar S, Bramryd T, Johansson M, Palo T (2018) Implementation of the ecosystem services approach in Swedish municipal planning. Journal of Environmental Policy \& Planning 20: 298-312

Seffel A, Möllegård J, Sernbo K, Eriksson Å, Barthel S, Andersson E (2014) Ekosystemtjänster ur ett kilperspektiv. Göteborgsregionens kommunalförbund och Ekologigruppen, Gothenburg

SEPA (2012) Sweden's environmental objectives-an introduction. Swedish Environmental Protection Agency Stockholm

SEPA (2018) Kommunikationssatsning om ekosystemtjänster. Report 6736. Swedish Environment Protection Agency, Stockholm

Sussams LW, Sheate WR, Eales RP (2015) Green infrastructure as a climate change adaptation policy intervention: muddying the waters or clearing a path to a more secure future? J Environ Manag 147: 184-193

TEEB (2011) TEEB Manual for Cities: Ecosystem Services in Urban Management. The Economics of Ecosystems and Biodiversity (TEEB): Geneva

Turkelboom F, Leone M, Jacobs S, Kelemen E, García-Llorente M, Baró F, Termansen M, Barton DN, Berry P, Stange E, Thoonen M, Kalóczkai Á, Vadineanu A, CASTRO AJ, Czúcz B, Röckmann C, Wurbs D, Odee D, Preda E, Gómez-Baggethun E, Rusch GM, Pastur GM, Palomo I, Dick J, Casaer J, Van Dijk J, Priess JA, Langemeyer J, Mustajoki J, Kopperoinen L, Baptist MJ, Peri PL, Mukhopadhyay R, Aszalós R, Roy SB, Luque S, Rusch V (2018) When we cannot have it all: ecosystem services trade-offs in the context of spatial planning. Ecosystem Services 29:566-578

Van Noord, M., Winkler, T (2014) Ekosystemförtjänster - från samråd till samfinansiering av ekosystemtjänster. c/o City

Wang J, Banzhaf E (2018) Towards a better understanding of green infrastructure: A critical review. Ecol Indic 85:758-772

Woodruff SC, Bendor TK (2016) Ecosystem services in urban planning: comparative paradigms and guidelines for high quality plans. Landsc Urban Plan 152:90-100

Yin RK (2014) Case study research: design and methods. Los Angeles: Sage 